\title{
Manajemen Pengelolaan Data pada Harmony Fitness Center Berbasis Web
}

\author{
Iksan Adiasa ${ }^{1)}$, Shinta Esabella*2), dan Anna Sayuni ${ }^{3)}$ \\ ${ }^{1)}$ Teknik Industri, Fakultas Teknik, Universitas Teknologi Sumbawa \\ Jl. Raya Olat Maras, Kabupaten Sumbawa, Nusa Tenggara Barat. 84371, Indonesia \\ ${ }^{2,3)}$ Teknik Informatika, Fakultas Teknik, Universitas Teknologi Sumbawa \\ Jl. Raya Olat Maras, Kabupaten Sumbawa, Nusa Tenggara Barat. 84371, Indonesia \\ Email: iksan.adiasa@uts.ac.id ${ }^{1)}$, shinta.esabella@uts.ac.id ${ }^{* 2)}$, annasayuni310398@ gmail.com ${ }^{3)}$
}

DOI: $10.20961 /$ performa.19.2.44830

\begin{abstract}
Abstrak
Harmony Fitness Center Sumbawa merupakan salah satu tempat fitness yang berdiri pada tahun 2019. Usaha ini bergerak di bidang olahraga untuk kesehatan dan kebugaran. Namun dalam melakukan pengelolaan data pada Harmony Fitness Center Sumbawa sendiri masih dilakukan secara manual yaitu dengan mencatat semua data menggunakan buku. Hal ini menjadikan pengelola fitness kesulitan dalam mengelola data yang setiap waktunya data tersebut selalu bertambah. Solusi dari permasalahan yang sedang terjadi adalah membangun sistem yang memudahkan pengelola dalam melakukan proses pengelolaan data yang ada. Maka dari itu tujuan dari penelitian ini adalah merancang dan membangun Manajemen Pengelolaan Data Pada Harmony Fitness Center Sumbawa Berbasis Web. Sistem ini dikembangkan menggunakan penelitian kualitatif dan dibangun menggunakan bahasa pemrogramman PHP dengan menggunakan MySql sebagai database. Metode yang digunakan dalam membangun aplikasi ini adalah menggunakan metode Prototype. Sistem atau aplikasi ini diharapkan dapat mempermudah dan mempercepat proses pengelolaan data pada Harmony Fitness Center Sumbawa.
\end{abstract}

Kata kunci: Harmony Fitness Center Sumbawa, Berbasis Web, Metode Prototipe

\begin{abstract}
Harmony Fitness Center Sumbawa is a fitness center that was established in 2019. This business is engaged in sports for health and fitness. However, data management at the Sumbawa Harmony Fitness Center is still done manually, namely by recording all data using books. This problem makes it difficult for fitness managers to manage data, which increases the data every time. The solution to the current problem is to build a system that makes it easier for managers to process existing data management. Therefore, the purpose of this study is to design and build a Web-based Data Management at Harmony Fitness Center Sumbawa. This system was developed using qualitative research and was built using the PHP programming language using MySql as a database. The method used in building this application is to use the Prototype method. This system or application is expected to simplify and speed up the data management process at the Sumbawa Harmony Fitness Center
\end{abstract}

Keywords: Harmony Fitness Center Sumbawa, Web-Based, Prototype Method

\section{Pendahuluan}

Harmony Fitness Center (HFC) yang beralamatkan di Jln. Hasanuddin No. 90, Kec. Sumbawa Besar, Kab. Sumbawa, Nusa Tenggara Barat yang didirikan oleh bapak Moh. Akbaruddin, S.STP, M.Tr.I.P. HFC merupakan usaha yang bergerak di bidang olahraga untuk kesehatan dan kebugaran yang saat ini telah memiliki member lebih dari 100 member. Kegiatan usaha ini melayani setiap pelanggan yang datang untuk melakukan olahraga fitness dengan menyediakan berbagai peralatan untuk menunjang kegiatan olahraga tersebut.

Sistem manajemen data yang berjalan pada HFC masih bersifat manual, yang masih dicatat pada buku besar, seperti pendaftaran anggota (harian, member, lanjut member) dan pelaporan harian. Pada pendaftaran anggota, pelanggan mendaftar langsung di HFC, kemudian pengelola HFC mencatat data pendaftar sesuai paket yang dipilih seperti harian, member, dan lanjut

${ }^{*}$ Corresponding author 
member. Kemudian setelah mendaftar pengelola akan memberitahu anggota fitness jadwal fitness sesuai paket yang di ambil pendaftar. Jika anggota harian ingin melanjutkan untuk menjadi member, maka pengelola fitness akan mencari data sebelumnya ataupun akan mencatat ulang data anggota jika data yang dicari lama atau sulit ditemukan. Fitness harian hanya berlaku sehari, sedangkan fitness member berlaku sebulan. Jadi, jika anggota ingin meneruskan fitness untuk bulan berikutnya, maka harus mendaftar ulang untuk menjadi member lanjut setiap bulannya. Pada pelaporan harian pengelola HFC akan menghitung jumlah pendaftar dan uang yang didapatkan dalam perhari, kemudian akan di setor ke rekening pemilik HFC. Tetapi pemilik HFC sendiri masih harus datang hanya untuk mengecek laporan harian. Sistem manual seperti ini kurang efisien, tidak cepat dan tidak akurat untuk pengolaan data di HFC.

Melihat permasalahan yang ada, maka HFC memerlukan suatu sistem yang bermanfaat untuk membantu aktivitas di HFC agar lebih mudah dalam mengelolah data, mengurangi resiko kesalahan menulis data, dapat mengefisienkan waktu dan tidak terjadinya penumpukan data dengan nama anggota yang sama karena terjadinya pencatatan data berulang kali. Pada penelitian ini, penulis akan membantu membuat suatu sistem yang dapat mempermudah pengelolaan data pada HFC. Pengelola HFC tidak perlu lagi mencatat secara manual data anggota fitness, karena anggota dapat mendaftar secara online agar data anggota secara otomatis langsung tersimpan, dan pengelola dapat menemukan data secara mudah. Pemilik HFC bisa lebih mudah untuk memonitoring pelaporan harian setiap harinya, seperti laporan jumlah pendaftar dan laporan pemasukan perharinya.

Sebagai perbandingan dan sumber acuan dalam merancang dan membangun Manajemen Pengelolaan Data di Harmony Fitness Center Sumbawa Berbasis Web, maka diperlukan acuan penelitian sebelumnya. Berdasarkan penelitian Mardinata (2017), yang berjudul "Membangun Sistem Informasi Pengelolahan Data Nasabah Berbasis Web di Bank Sampah Samawa", sistem yang berjalan masih bersifat manual dalam pencatatan dan perekapan transaksi nasabah masih menggunakan buku sehingga data transaksi nasabah dikhawatirkan akan menyulitkan pengelola dalam mencatat dan merekap data tabungan nasabah. Untuk itu Bank Sampah Samawa memerlukan teknologi informasi yang bertujuan untuk mempermudah pengelolahan data transaksi dan perekapan data nasabah, sehingga pencatatan dan perekapan data nasabah lebih mudah karena data-data tersebut telah tersimpan secara terstruktur di dalam database. Web adalah sebuah software yang berfungsi untuk menampilkan dokumen-dokumen pada suatu web yang membuat pengguna dapat mengakses melalui software yang terkoneksi dengan internet (Destiningrum dan Qadhil, 2017).

Pada penelitian ini dilakukan manajemen pengelolaan data pada FCW berbasis web. Manajemen adalah sebuah proses pemanfaatan terhadap sumber daya yang ada dalam organisasi, baik sumber manusia maupun sumber-sumber lain melalui proses perencanaan, pengorganisasian, penggerakan dan pengontrolan yang dilakukan secara sistematis (Dewi dan Ali, 2019). Selain itu manajemen adalah suatu proses dalam rangka mencapai tujuan dengan kerjasama melalui orang-orang dan sumber daya organisasi lainnya (Elbadiansyah, 2018).

\section{Metode Penelitian}

Adapun metode yang digunakan dalam penelitian ini yaitu proses pengumpulan data dan pengembangan perangat lunak. Adapun tahapan-tahapan yang digunakan dalam membangun sistem ini adalah dutunjukkan pada gambar 1 berikut: 


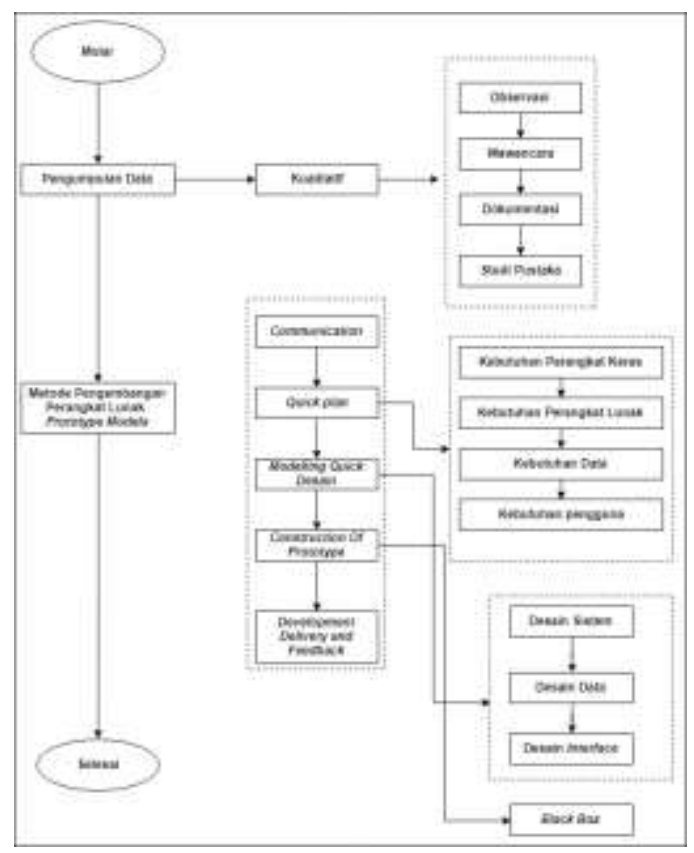

Gambar 1. Alur Metode Penelitian

\section{A. Metode Pengumpulan Data}

Pengumpulan data pada penelitian ini diawali dengan melakukan observasi. Pada tahap ini peneliti melakukan survei lokasi langsung dan melakukan pengamatan terhadap objek penelitian untuk mengumpulkan data-data HFC. Survei ini dilakukan untuk mencari data member, data calon member, data instruktur dan data transaksi. Selanjutnya adalah tahap wawancara. Pada tahap ini peneliti melakukan wawancara terhadap Personal Trainer HFC untuk tukar informasi mengenai permasalahan- permasalahan yang ada di HFC. Tahap selanjutnya adalah studi pustaka. Pada tahap ini peneliti mempelajari konsep, teknik, maupun informasi dari berbagai sumber seperti internet, buku, jurnal, maupun artikel ilmiah lainnya yang berkaitan dengan manajemen pengelolaan data.

\section{B. Metode Pengembangan Perangkat Lunak}

Pada penelitian ini peneliti menggunakan metode pengembangan perangkat lunak Software Development Life Cycle (SDLC) dengan model Prototipe. Software Development Life Cycle (SDLC) atau sering disebut juga System Development Life Cycle adalah proses mengembangkan atau mengubah suatu sistem perangkat lunak dengan menggunakan modelmodel dan metodologi yang digunakan orang untuk mengembangkan sistem-sistem perangkat lunak sebelumya (berdasarkan best practice atau cara-cara yang sudah teruji baik) (Pressman, 2012). SDLC memiliki beberapa model dalam penerapan tahapan prosesnya antara lain model waterfall, model prototipe, model RAD, model iteratif, dan model spiral. Pada penelitian ini menggunakanan model prototipe. Model prototipe terdiri dari lima tahapan yaitu Communication (komunikasi), Quick Plan (perencanaan secara cepat), Modeling Quick Design (model rancangan cepat), Construction of Prototype (Pembuatan prototype), dan Deployment Delivery \& Feedback (Penyerahan dan pemberikan umpan balik terhadap pengembangan). Menurut Pressman (2012), metode pengembangan perangkat lunak ini cocok digunakan untuk membuat sistem baru dan menggembangkan sebuah perangkat yang akan dikembangkan kembali sesuatu kebutuhan pengguna. 


\section{Communication}

Pada tahapan ini peneliti melakukan komunikasi atau wawancara langsung dengan pengelola di HFC, untuk mengetahui masalah yang ada di HFC.

\section{Quick Plan}

Setelah mendapatkan dan mengetahui seluruh masalah yang ada, maka tahap selanjutnya peneliti menganalisis kebutuhan perangkat keras, kebutuhan perangkat lunak, kebutuhan data dan kebutuhan pengguna untuk membangun suatu sistem untuk menyelesaikan masalah yang ada di HFC.

\section{Modeling Quick Design}

Setelah mendapatkan dan mengetahui seluruh kebutuhan yang diperlukan, maka selanjutnya dilakukan pembuatan rancangan untuk model rancangan sistem, data dan interface. Tahap awal yang akan dilakukan peneliti yaitu perancangan sistem menggunakan teknik UML, kemudian tahap kedua yaitu melakuka perancangan data, dan terakhir perancangan interface. UML merupakan sebuah bahasa pemodelan yang telah menjadi standar dalam industri software untuk visualisasi, merancang, dan mendokumentasi sistem perangkat lunak. Desain yang dihasilkan berupa diagram-diagram UML yang akan diterjemahkan menjadi kode program pada tahap implementasi dan terdapat 13 jenis diagram resmi yang digunakan dalam perancangan berorientasi objek berbasis UML (Fajarianto, 2016).

\section{Construction of Prototype}

Setelah mendapatkan dan mengetahui seluruh kebutuhan yang diperlukan dan model rancangan sistem maka selanjutnya dilakukan pembuatan sistem dengan menulis kode program sistem yang akan digunakan. Pengkodean program menggunakan bahasa pemrograman dasar berbasis web yaitu HTML, CSS, PHP, dan JavaScript dengan framework Codelgniter sebagai kerangka kerja. Bahasa pemrograman yang digunakan dalam penelitian ini yaitu bahasa pemrograman PHP. PHP merupakan bahasa pemrograman yang digunakan untuk membuat website dinamis dan interaktif. Dinamis artinya, website tersebut bisa berubah-ubah tampilan dan kontennya sesuai kondisi tertentu. Sebagai contoh, PHP bisa menampilkan tanggal dan hari saat ini secara berganti-ganti didalam sebuah website. Interaktif artinya, PHP dapat memberi feedback bagi pengguna (misalnya menampilkan hasil pencarian produk) (Enterprise, 2017). CodeIgniter adalah sebuah web application framework yang bersifat open source digunakan untuk membangun aplikasi PHP dinamis. Tujuan utama pengembangan CodeIgniter adalah untuk membantu developer untuk mengerjakan aplikasi yang lebih cepat dari pada menulis code dari awal (Daqiqil, 2011). Sistem yang telah selesai dibangun melalui tahap coding, kemudian dilakukan pengujian sistem. Hal ini dilakukan untuk memastikan bahwa perangkat lunak yang telah dibuat dapat digunakan dengan baik dan sudah layak pakai atau perlu untuk disempurnakan lagi. Dalam penelitian ini akan digunakan pengujian terhadap prototipe dengan menggunakan metode pengujian Black-box testing memungkinkan penguji perangkat lunak untuk melakukan serangkaian pengujian berdasarkan masukan (input) sesuai dengan kondisi tertentu yang akan mengerjakan tugas - tugas dari keseluruhan kebutuhan fungsi sebuah program.

\section{Deployment Delivery \& Feedback}

Tahap akhir yaitu penyerahan aplikasi yang dibuat untuk melakukan evaluasi jika terdapat kekurangan dan memberikan umpan balik untuk pengembangan selanjutnya. 


\section{Hasil dan Pembahasan}

Sistem yang sedang berjalan pada Harmony Fitness Center Sumbawa akan dijelaskan pada gambar 2.

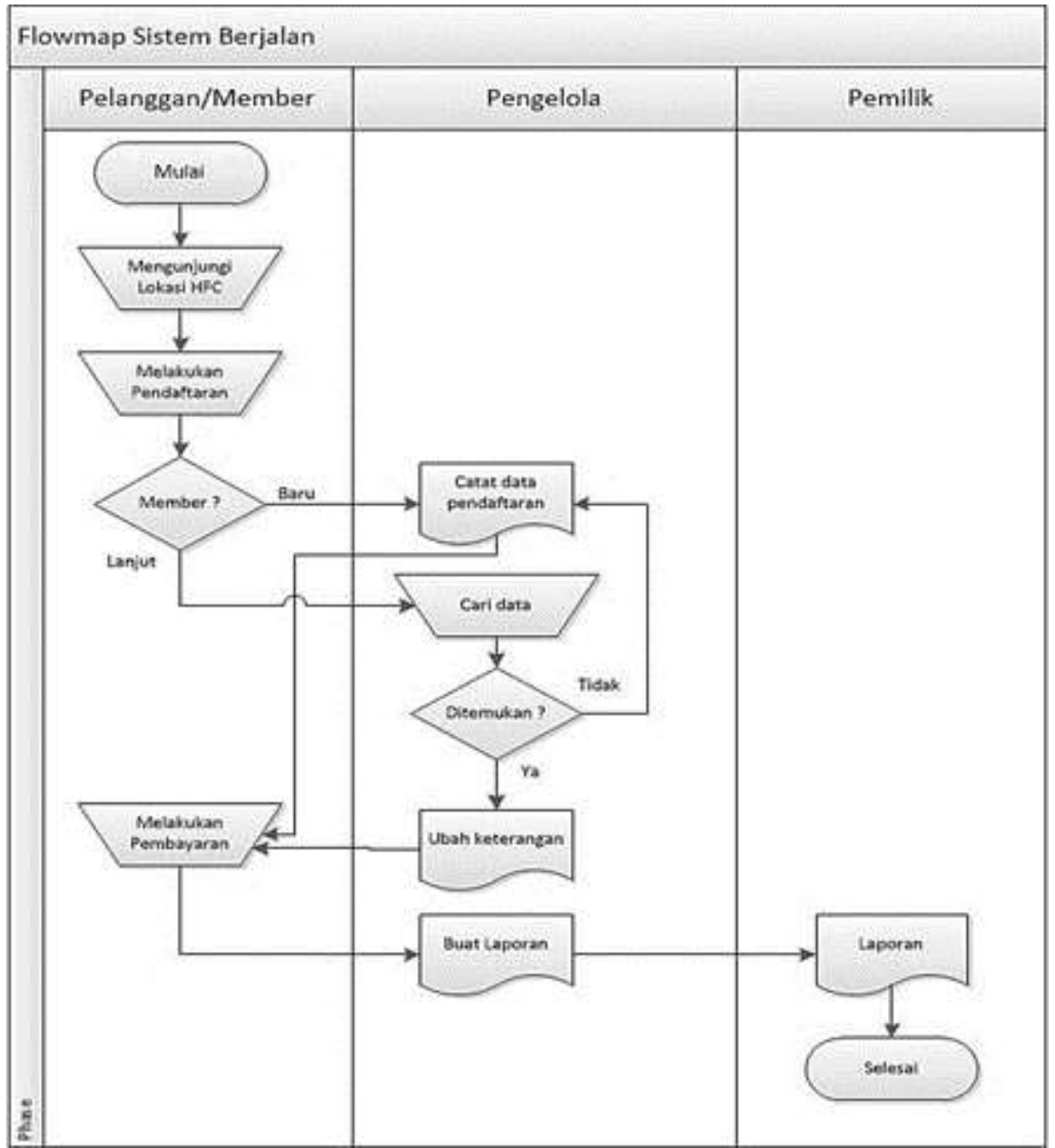

Gambar 2. Sistem Berjalan Di HFC

Berdasarkan gambar 2, pengelolaan data di HFC masih bersifat manual, yang dimana saat pelanggan ingin mendaftar fitness maka harus secara langsung datang ke lokasi fitness dan pengelola HFC akan mencatat data pelanggan secara manual di buku, jika pelanggan ingin melanjutkan member maka pengelola harus mencari data sebelumnya dibuku, apabila data tidak di temukan dalam buku maka pengelola akan mencatat ulang data yang sama lagi dan pelanggan melakukan pembayaran. Setelah itu pengelola HFC akan membuat laporan harian secara manual untuk dilihat secara langsung oleh pemilik.

Adapun sistem yang diusulkan penulis untuk digunakan pada Harmony Fitness Center Sumbawa sebagai berikut: 


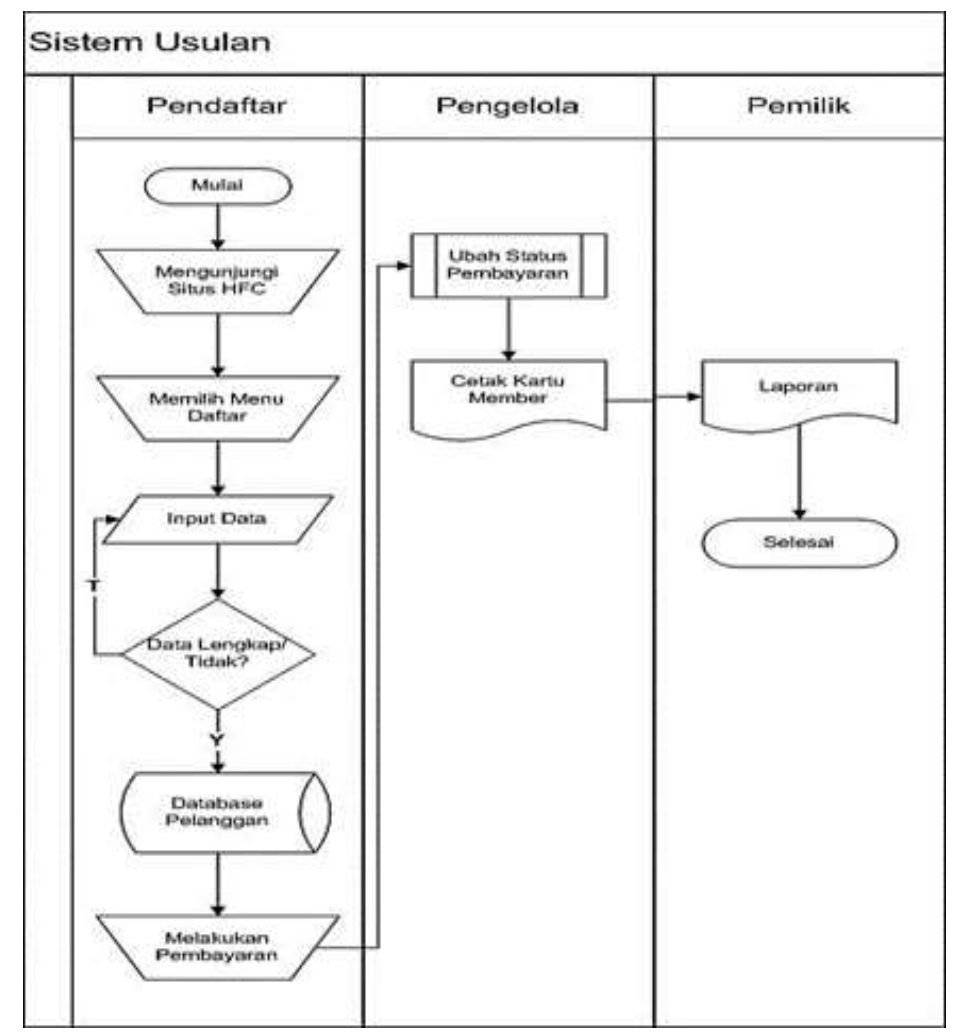

Gambar 3. Sistem Usulan

Berdasarkan gambar diatas, pelanggan bisa melakukan pendaftaran secara online dengan cara mengunjungi situs HFC. Pelanggan dapat memilih menu daftar untuk melakukan pendaftaran, kemudian pelanggan akan menginput datas, jika data yang diisi lengkap maka data akan tersimpan di database tetapi jika data yang diisi belum lengkap maka pelanggan harus mengisi lagi. Setelah pelanggan melakukan pembayaran secara langsung di HFC maka pengelola akan mengubah status pembayaran, setelah itu mencetak kartu dan pemilik bisa melihat laporan.

\section{Use Case Diagram}

Use case adalah kegiatan atau urutan interaksi yang saling berkaitan antara sistem dan aktor. Berikut adalah gambar keseleruhan sistem manajemen pengeloloaan data pada harmony fitness center Sumbawa.

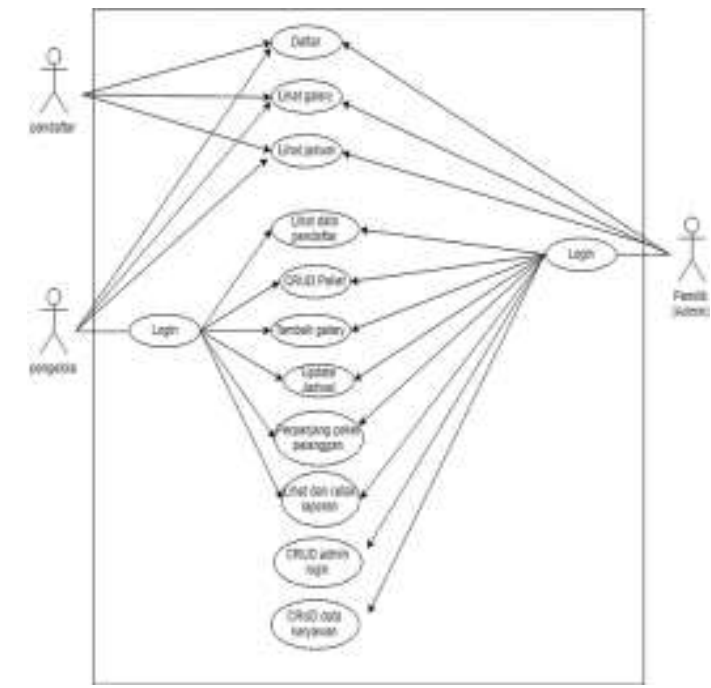

Gambar 4. Use Case Diagram 
Berdasarkan gambar 4 mendeskripsikan bahwa pendaftar dapat melakukan pendaftaran, lihat galeri, dan lihat jadwal. Pengelola mempunyai akses terhadap beberapa fitur, tetapi untuk dapat melihat data pendaftar, CRUD paket, tambah galeri, update jadwal, perpanjang paket, dan lihat serta cetak laporan, pengelola harus login terdahulu. Pemilik sebagai admin mempunyai hak akses lebih dari pengelola, dimana pemilik juga harus login terdahulu untuk dapat mengakses fitur yang diinginkan. Pemilik mempunyai hak akses terhadap beberapa fitur yang berbeda dari pengelola yaitu CRUD admin login, CRUD data karyawan dan lihat serta cetak laporan. Hak akses fitur yang sama dengan pengelola, pemilik hanya dapat memonitoring atau melihat saja tidak dapat mengolah data yang ada, karena pemilik hanya bertugas memonitoring dan memberikan hak akses terhadap pengelola untuk mengolah data.

\section{Activity Diagram Daftar}

Berikut adalah gambar activity diagram daftar untuk pendaftar dimana gambar ini merupakan alur sistem dari pendaftar ketika melakukan pendaftaran.

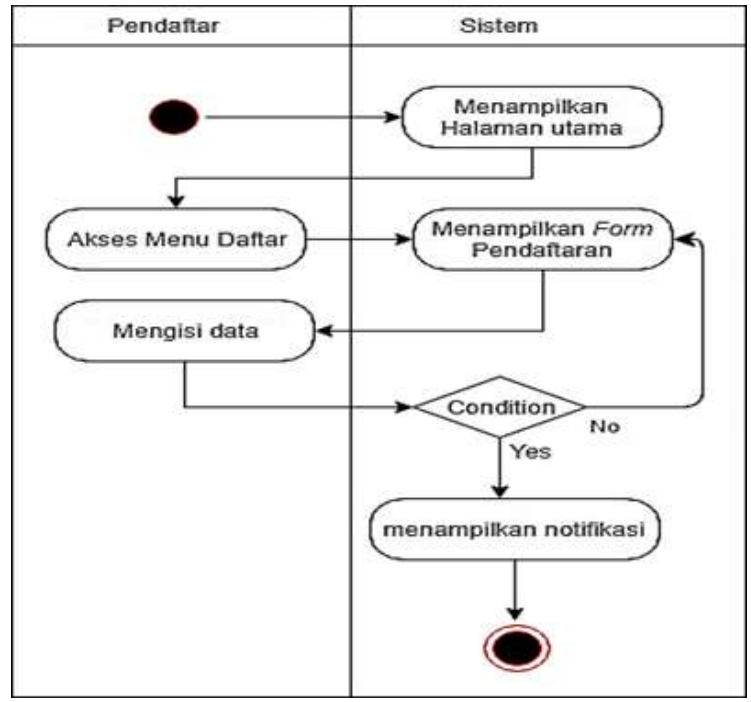

Gambar 5. Activity Diagram Daftar

Pada activity diagram gambar 5, menggambarkan alur proses dari sistem yaitu saat pendaftar memulai sistem menampilkan halaman utama, pada halaman utama pendaftar mengakses menu daftar. Setelah mengakses menu daftar maka sistem menampilkan form pendaftaran, kemudian pendaftar mengisi data sesuai instruksi. Jika data yang diisi lengkap, sistem akan menampilkan notifikasi, dan jika data yang diisi belum lengkap maka sistem akan menampilkan form pendaftaran lagi.

\section{Sequence Diagram Daftar}

Berikut merupakan sequence diagram daftar untuk pendaftar dimana gambar 6 berikut adalah alur sistem bagaimana proses mendaftar dalam aplikasi. 


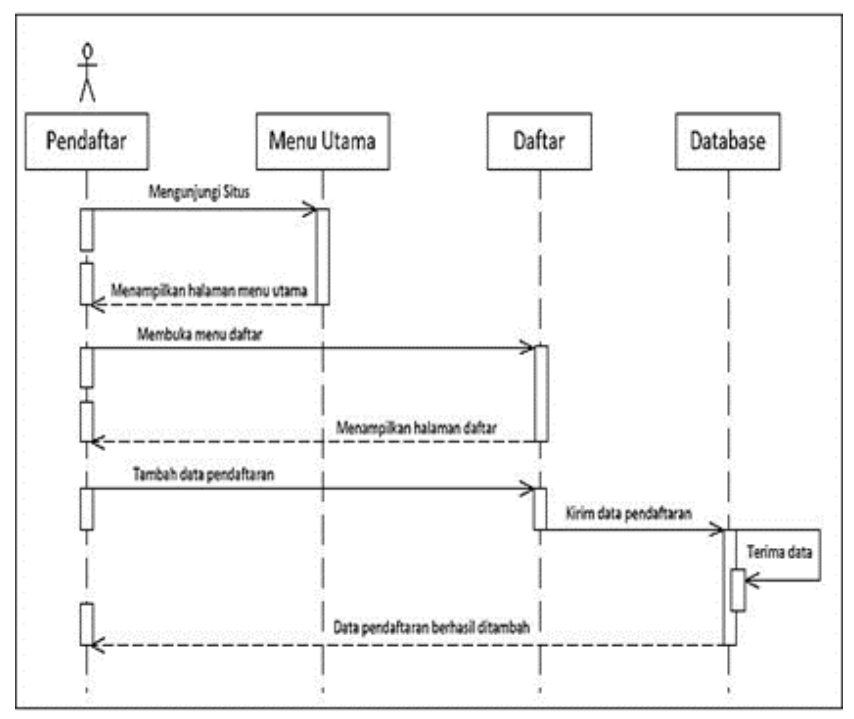

Gambar 6. Sequence Diagram Daftar

Proses dimulai yaitu pada saat pendaftar mengunjungi situs maka sistem akan menampilkan halaman menu utama kemudian pendaftar membuka menu daftar dan sistem akan menampilkan halaman untuk melakukan pendaftaran. Setelah pendaftar mengisi data, maka data pendaftar akan dikirim ke database untuk disimpan, data akan diterima dan pendaftar berhasil ditambah.

\section{Rancangan Halaman Login}

Berikut adalah tampilan rancangan halaman login.

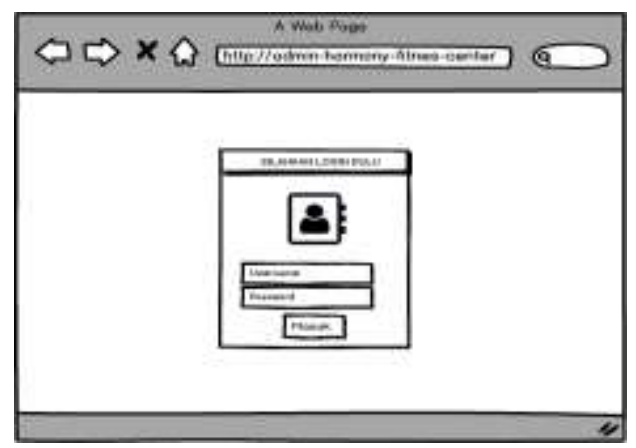

Gambar 7. Rancangan Halaman Login

Tampilan rancangan halaman login merupakan rancangan tampilan awal dari sistem ketika admin pertama kali menjalankan sistem. Pada rancangan ini terdapat dua form input-an yaitu nama pengguna dan kata sandi dimana admin dan pengelola harus mengisi data dengan benar jika ingin masuk kedalam sistem untuk mengelolah data.

\section{Rancangan Halaman Daftar}

Berikut ini adalah tampilan rancangan halaman daftar. 


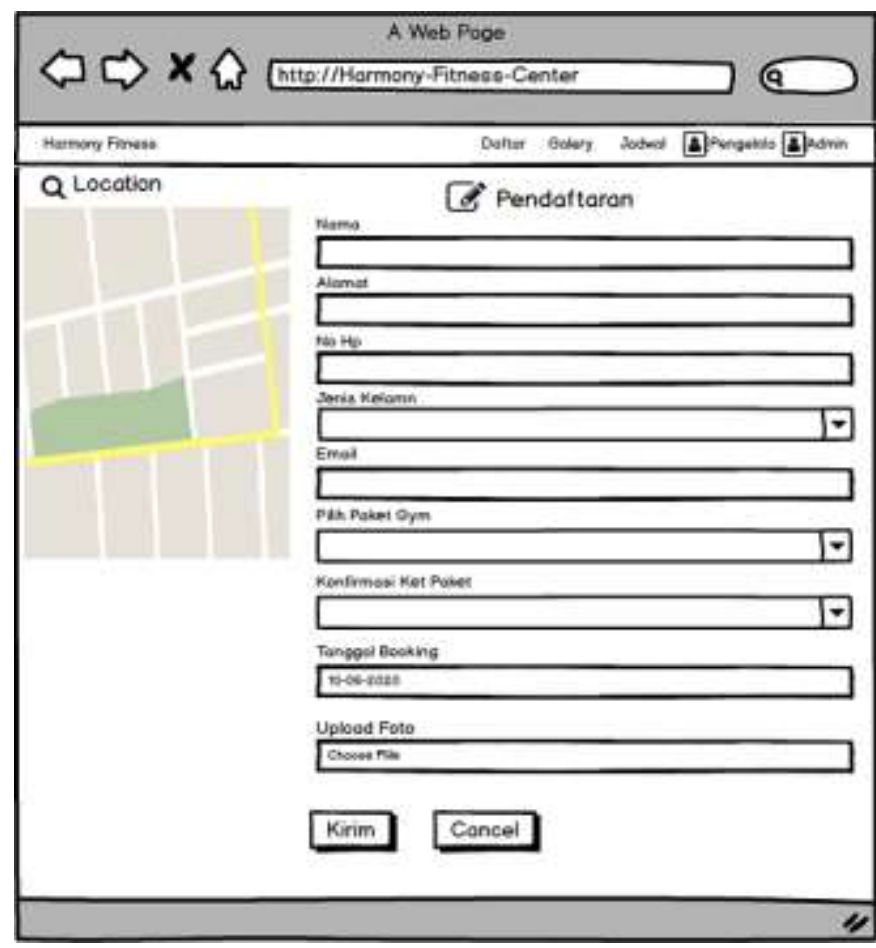

Gambar 8. Rancangan Halaman Daftar

Tampilan rancangan daftar akan menampilkan beberapa form input-an data pendaftar fitness seperti nama, alamat, no.hp, email, tanggal boking dan jenis kelamin, pilih paket gym, konfirmasi keterangan paket merupakan input-an combobox untuk memilih dan upload foto. Di rancangan halaman pendaftaran ini juga terdapat button kirim yang fungsinya akan menyimpan data, dan button cancel yang funsinya untuk membatalkan pendaftaran.

\section{Rancangan Halaman Lihat Data Pendaftar}

Berikut adalah tampilan rancangan halaman lihat pendaftar.

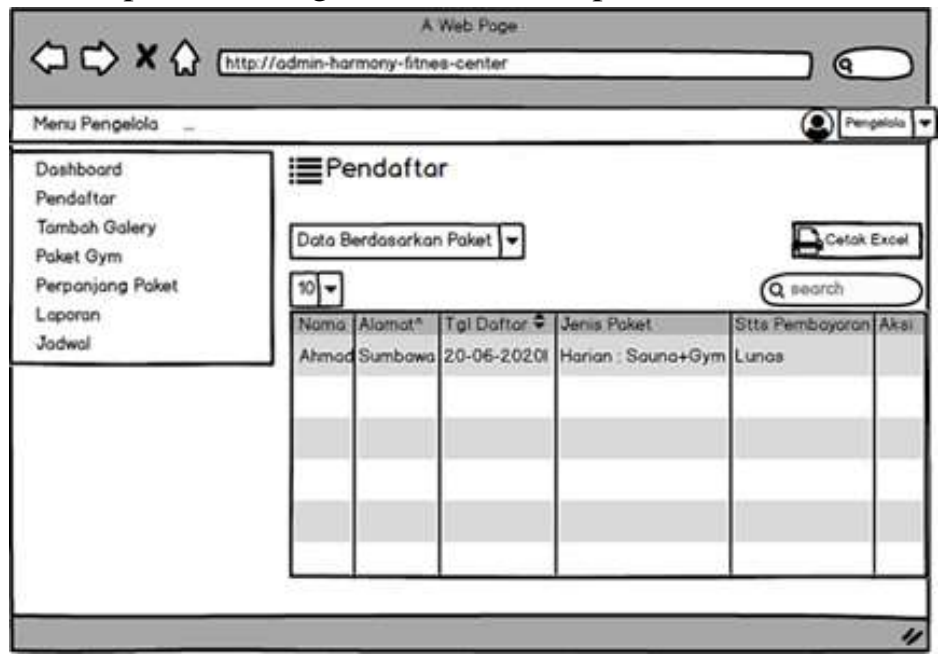

Gambar 9. Rancangan Halaman Lihat Data Pendaftar

Rancangan tampilan data pendaftar ini menampilkan data pendaftar fitness yang diambil dari tabel database pelanggan berupa nama pendaftar, alamat, tanggal daftar, jenis paket dan status pembayaran. 


\section{Tampilan Halaman Login Admin}

Berikut adalah tampilan halaman login aplikasi manajemen pengelolaan data pada HFC.

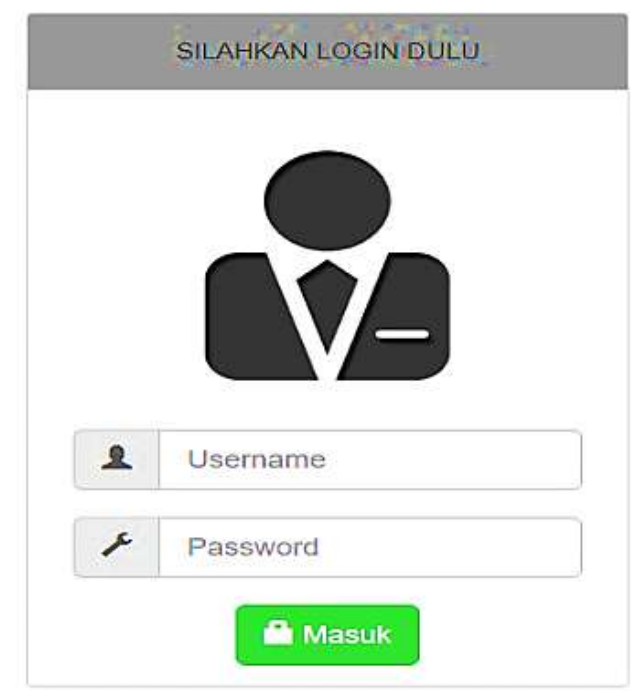

Gambar 10. Tampilan Halaman Login Admin

Gambar 10 merupakan hasil atau implementasi sistem dari form login admin (pengelola) yang menampilkan username dan password yang harus diisi admin untuk mengakses sistem dalam mengolah data.

\section{Tampilan Halaman Utama}

Berikut adalah tampilan halaman utama aplikasi manajemen pengelolaan data pada HFC.

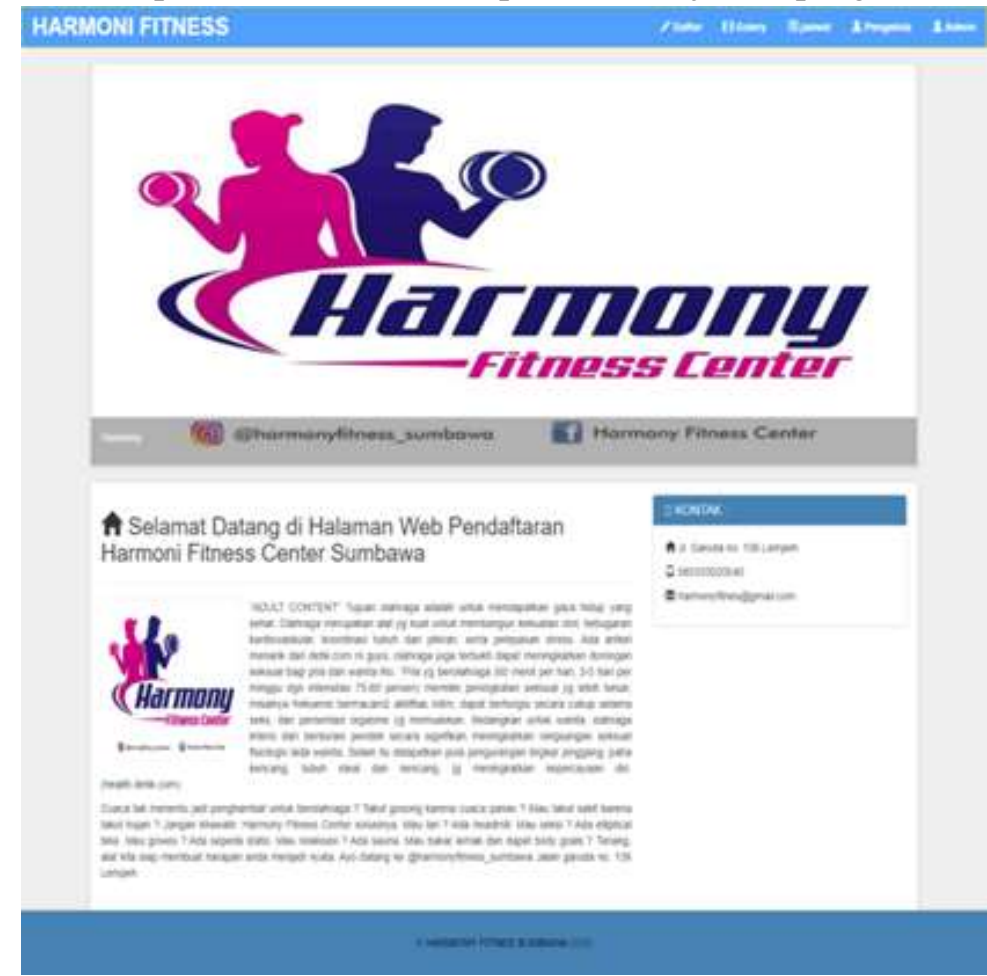

Gambar 11. Tampilan Halaman Utama

Gambar 11 merupakan hasil atau implementasi sistem dari halaman utama yang menampilkan beberapa informasi dan menu. 


\section{Tampilan Halaman Daftar}

Berikut adalah tampilan halaman daftar aplikasi manajemen pengelolaan data pada HFC.

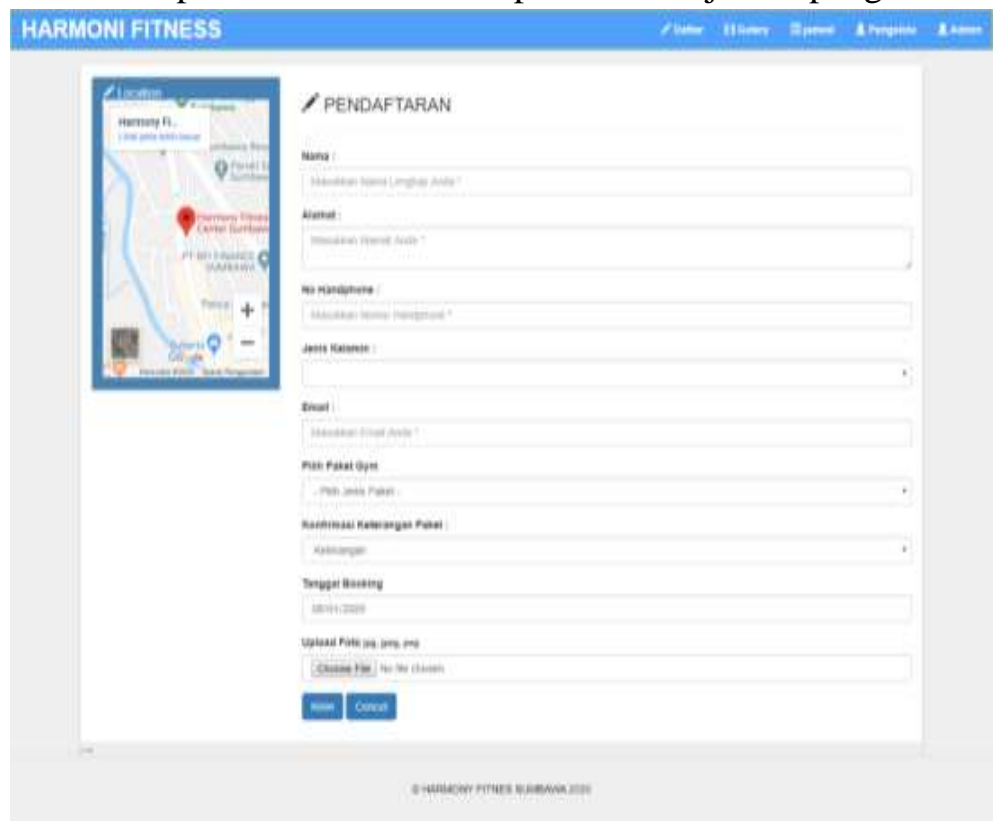

Gambar 12. Tampilan Halaman Daftar

Gambar 12 merupakan tampilan implementasi sistem dari perancangan form pendaftaran yang berfungsi untuk mengisi data data pendaftar fitness.

\section{Tampilan Halaman Lihat Data Pendaftar}

Berikut adalah tampilan halaman lihat data pendaftar untuk pengelola pada aplikasi manajemen pengelolaan data pada HFC.

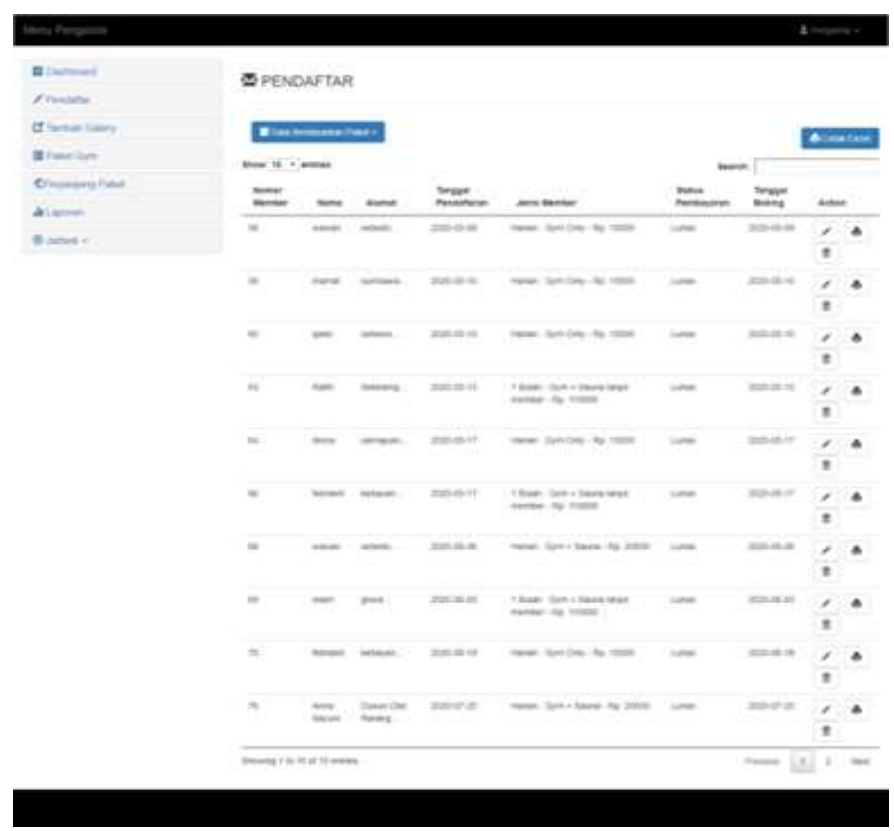

Gambar 13. Tampilan Halaman Lihat Data Pendaftar 
Gambar 13 merupakan implementasi sistem dari perancangan halaman lihat data pendaftar yang berfungsi untuk menampilkan data pendaftaran fitness.

Setelah sistem dibuat, dilakukan pengujian menggunakan blackbox. Adapun menu yang diuji yaitu data pendaftaran member, login, dan paket gym. Di data pendaftaran member detail pengujiannya yaitu kirim dan batal, menu login detail pengujiannya yaitu sebagai admin (pengelola) dan superadmin (pemilik), dan menu paket fitness detail pengujiannya yaitu tambah, edit, hapus. Berikut adalah pengujian pendaftaran member yang ditunjukkan pada tabel 1 .

Tabel 1. Pengujian Pendaftaran Member

\begin{tabular}{|l|l|l|l|}
\hline \multicolumn{5}{|c|}{ Kasus dan Hasil Uji (data benar) } \\
\hline Data masukan & Yang diharapkan & Pengamatan & Kesimpulan \\
\hline $\begin{array}{l}\text { Data diisi sesuai } \\
\text { perintah dan } \\
\text { ketentuan }\end{array}$ & $\begin{array}{l}\text { Ketika data yang } \\
\text { diisi selesai } \\
\text { dilakukan klik } \\
\text { tombol kirim, data } \\
\text { yang baru akan } \\
\text { masuk ke database }\end{array}$ & $\begin{array}{l}\text { Tombol kirim } \\
\text { berfungsi, data yang } \\
\text { diisi sukses } \\
\text { dimasukkan setelah } \\
\text { pilih tombol kirim }\end{array}$ & Diterima \\
\hline \multicolumn{5}{|c|}{ Kasus dan Hasil Uji (data salah) } & \\
\hline Data masukan & Yang diharapkan & Pengamatan & Kesimpulan \\
\hline $\begin{array}{l}\text { Ada salah satu data } \\
\text { diisi tidak sesuai } \\
\text { perintah. Contoh : } \\
\text { Email : } \\
\text { 085333020040 }\end{array}$ & $\begin{array}{l}\text { Ketika tombol kirim } \\
\text { dipilih kursor akan } \\
\text { hidup di kolom } \\
\text { Email pertanda } \\
\text { bahwa data yang } \\
\text { dimasukkan salah }\end{array}$ & $\begin{array}{l}\text { Tombol kirim tidak } \\
\text { berfungsi }\end{array}$ & Diterima \\
\hline
\end{tabular}

Pengujian pendaftaran dilakukan sebanyak dua kasus yaitu data masukkan benar dan data masukkan salah. Pada data masukkan benar yang diuji yaitu semua perintah diisi sesuai perintah, ketika tombol kirim dipilih maka akan menampilkan pesan data berhasil dikirim. pada kasus data masukkan salah ada satu perintah yang salah diisi yaitu perintah masukkan email, ketika tombol kirim dipilih akan menampilkan pesan data yang dimasukkan salah. Dari hasil pengujian tersebut, dapat disimpulkan bahwa fungsi yang diuji dapat diterima.

Tabel 2. Pengujian Login

\begin{tabular}{|c|c|c|c|}
\hline \multicolumn{4}{|c|}{ Kasus dan Hasil Uii (data benar) } \\
\hline Data masukan & Yang diharapkan & Pengamatan & Kesimpulan \\
\hline $\begin{array}{l}\text { Username : admin } \\
\text { Password : admin }\end{array}$ & Login berhasil & $\begin{array}{l}\text { Username dan } \\
\text { Password diisi } \\
\text { sesuai dengan tabel } \\
\text { Login. } \\
\text { Login berhasil }\end{array}$ & Diterima \\
\hline \multicolumn{4}{|c|}{ Kasus dan Hasil Uji (data salah) } \\
\hline Data masukan & Yang diharapkan & Pengamatan & Kesimpulan \\
\hline $\begin{array}{l}\text { Username dan } \\
\text { password tidak } \\
\text { terdaftar } \\
\text { Contoh: } \\
\text { Username : maman } \\
\text { Password : } 12345 \\
\end{array}$ & $\begin{array}{l}\text { Tidak dapat login } \\
\text { dan menampilkan } \\
\text { pesan kesalahan }\end{array}$ & $\begin{array}{l}\text { Tidak dapat login } \\
\text { dan menampilkan } \\
\text { pesan kesalahan } \\
\text { sesuai dengan yang } \\
\text { diharapkan }\end{array}$ & Diterima \\
\hline
\end{tabular}

Pengujian login dilakukan sebanyak dua kasus yaitu data masukkan benar dan data masukkan salah. Pada data masukkan benar Username dan Password diisi sesuai ketentuan, sehingga login dapat berhasil. Pada kasus data masukkan salah Username dan Password diisi bebas atau tidak sesuai ketentuan, login tidak dapat berhasil dan sistem menampilkan pesan 
kesalahan. Dari hasil pengujian login, baik data masukkan benar dan data masukkan salah dapat disimpulkan bahwa menu login dapat diterima.

Berikut adalah pengujian paket fitness yang ditunjukkan pada tabel 3.

Tabel 3. Pengujian Paket Fitness

\begin{tabular}{|l|l|l|l|}
\hline \multicolumn{5}{|c|}{ Kasus dan Hasil Uji (data benar) } \\
\hline Data masukan & Yang diharapkan & Pengamatan & Kesimpulan \\
\hline $\begin{array}{l}\text { Data diisi sesuai } \\
\text { perintah }\end{array}$ & $\begin{array}{l}\text { Jika data selesai } \\
\text { diisi kemudian pilih } \\
\text { tombol Save maka } \\
\text { data berhasil } \\
\text { disimpan ke databse }\end{array}$ & $\begin{array}{l}\text { Tombol Save } \\
\text { berfungsi, data } \\
\text { berhasil disimpan ke } \\
\text { database }\end{array}$ & Diterima \\
\hline \multicolumn{4}{|c|}{ Kasus dan Hasil Uji (data salah) } \\
\hline Data masukan & Yang diharapkan & Pengamatan & Kesimpulan \\
\hline $\begin{array}{l}\text { Ada salah satu data } \\
\text { tidak diisi }\end{array}$ & $\begin{array}{l}\text { Ketika tombol Save } \\
\text { dipilih akan } \\
\text { menampilkan pesan } \\
\text { kesalahan data harus } \\
\text { diisi }\end{array}$ & $\begin{array}{l}\text { Tombol Save tidak } \\
\text { berfungsi dan } \\
\text { menampilkan pesan } \\
\text { kesalahan }\end{array}$ & Diterima \\
\hline
\end{tabular}

Pengujian paket fitness dilakukan sebanyak dua kasus yaitu data masukkan benar dan data masukkan salah. Pada data masukkan benar yang diuji yaitu semua perintah diisi sesuai perintah, ketika tombol simpan dipilih maka akan menampilkan pesan berhasil disimpan. pada kasus data masukkan salah ada satu perintah yang tidak diisi yaitu perintah masukkan julukan, ketika tombol simpan dipilih akan menampilkan pesan julukan harus diisi. Dari hasil pengujian tersebut, dapat disimpulkan bahwa fungsi yang diuji dapat diterima.

\section{Simpulan}

Dari hasil analisis dan perancangan sistem yang telah dilakukan sebelumnya, maka penulis dapat mengambil kesimpulan bahwa manajemen pengelolaan data pada harmony fitness center Sumbawa berbasis web telah selesai dibangun menggunakan bahasa pemrogramman PHP dengan framework CodeIgniter, database MySql, dan berhasil diuji menggunakan blackbox dengan hasil uji diterima yang dapat digunakan oleh harmony fitness center sumbawa untuk mempermudah dan mempercepat pengelola dalam mengelola data yang ada, dan pemilik lebih mudah dalam memonitoring laporan yang ada, serta pelanggan bisa mendaftar tanpa harus ke lokasi langsung. Namun masih terdapat beberapa kekurangan dalam web ini, sehingga untuk pengembang aplikasi ini kedepannya dapat menambahkan fitur transaksi pembayaran secara online, aplikasi dapat dikembangakan berbasis multiplatform dengan bahasa pemrograman terbaru.

\section{Daftar Pustaka}

Daqiqil, I. (2011). Framework CodeIgniter Panduan dan Best Practice. Pekanbaru: Andi.

Destiningrum, M \& Qadhil, J.A. (2017). Sistem Informasi penjadwalan Dokter Berbasis Web dengan Menggunakan Framework CodeIgniter. Jurnal TEKNOINFO, Vol. 11, No.2. Diakses pada tanggal 14 Maret 2020.

Dewi, I. K., \& Ali, M. (2019). Nilai-Nilai Profetik dalam Kepemimpinan Modern pada Manajemen Kerja. Yogyakart: Gre Publishing.

Elbadiansyah. (2018). Manajemen Sumber Daya Manusia. Malang: CV IRDH

Enterprise, J. (2018). HTML, PHP, dan MySQL untuk Pemula. Jakarta: Elex Media Komputindo. 
Fajarianto, O. (2016). Prototype Pelayanan Akademik Terhadap Komplain Mahasiswa Berbasis Android. Jurnal Lentera ICT, Vol. 3 No. 1 Hal. 55. Diakses pada tanggal 14 Maret 2020.

Mardinata, E., \& Khair, S. (2017). Membangun Sistem Informasi Pengelolaan Data Nasabah Berbasis Web Di Bank Sampah Samawa. Jurnal Matrik, 17(1). Diaksed pada tanggal 14 Maret 2020.

Pressman, R. S. (2012). Rekayasa Perangkat Lunak (Pendekatan Praktisi)"Edisi 7: Buku 1. Yogyakarta: Andi. 